\title{
ANALISIS DAYA DUKUNG HIJAUAN PAKAN TERNAK DI KECAMATAN PULOKULON KABUPATEN GROBOGAN UNTUK PENGEMBANGAN USAHA TERNAK SAPI POTONG
}

\author{
Ria Tanjaya, Dewi Hastuti, Hendri Wibowo, dan Aniya Widiyani \\ Program Studi Agribisnis, Fakultas Pertanian, Universitas Wahid Hasyim \\ e-mail: ria.tanjaya@gmail.com
}

\begin{abstract}
ABSTRAK
Indonesia merupakan negara berkembang yang berbasis pertanian termasuk di dalamnya peternakan. Di Kecamatan Pulokulon Kabupaten Grobogan populasi sapi potong mencapai 18.858 ekor dan luas panen tanaman pangan mencapai 6.186 hektar. Saat ini, produksi daging sapi Indonesia masih rendah. Berdasarkan permasalahan ini maka dilakukan penelitian dengan tujuan untuk mengetahui indeks daya dukung (IDD) hijauan pakan dan kapasitas penambahan ternak sapi potong di Kecamatan Pulokulon. Metode penelitian yang digunakan adalah deskriptif analitis. Pemilihan lokasi menggunakan purposive sampling dengan pertimbangan lokasi penelitian memiliki populasi sapi potong 5 besar dari kecamatan yang ada di Kabupaten Grobogan. Data yang digunakan dalam penelitian adalah sekunder yang bersumber dari BPS Kabupaten Grobogan dan Dinas Peternakan dan Perikanan Kabupaten Grobogan. Data kemudian diolah dan dianalisis menggunakan IDD (indeks daya dukung) pakan. Dari data BPS 2018, Jumlah penduduk tahun 2018 sebanyak 108.422 jiwa atau 36.003 KK dengan luas wilayah 13.365 hektar. Hasil penelitian menunjukan bahwa Kecamatan Pulokulon memiliki nilai IDD 3,43 (>2) yang menunjukkan ketersediaan pakan masih aman dan dapat menambah populasi ternak sebanyak 8.782,23 satuan ternak dari populasi yang ada yaitu 12.281,28 satuan ternak.
\end{abstract}

Kata kunci: sapi potong, IDD (indeks daya dukung), hijauan pakan, pengembangan usaha, Kecamatan Pulokulon

\section{ANALYSIS OF THE CARRYING CAPACITY OF FEED FOR LIVESTOCK IN PULOKULON SUB-DISTRICT OF GROBOGAN DISTRICT FOR DEVELOPMENT OF CATTLE BUSINESS}

\begin{abstract}
Indonesia is a developing country based on agriculture including animal husbandry. In Pulokulon District, Grobogan Regency, the population of beef cattle reaches 18.858 and the harvested area of food crops reaches 6,186 hectares. At present, Indonesian beef production is still low. Based on this problem, a study was conducted with the aim of finding out the forage carrying capacity index (CCI) of forage and the addition capacity of beef cattle in Pulokulon District. The research method used is descriptive analytical. Site selection using purposive sampling with consideration of the location of the study has a population of 5 large beef cattle from districts in Grobogan Regency. The data used in the study are secondary sourced from BPS Grobogan Regency and the Department of Animal Husbandry and Fisheries Grobogan Regency. The data is then processed and analyzed using CCI (carrying capacity index) feed. From 2018 BPS data, the total population in 2018 was 108,422 people or 36,003 households with an area of 13,365 hectares. The results showed that the Pulokulon Subdistrict had an CCI value of $3,43(>2)$ which indicated the availability of feed was still safe and could increase the livestock population to 8,782.23 animal units from the existing population of $12,281.28$ animal units.
\end{abstract}

Keywords: beef cattle, CCI (carrying capacity index), forage forage, business development, Pulokulon Distric

\section{PENDAHULUAN}

Pengembangan usaha ternak sapi potong memiliki prospek yang yang bagus. Seiring meningkatnya jumlah penduduk, hal ini mengakibatkan permintaan akan daging dan susu sapi sebagai pemenuhan gizi meningkat. Sebagai upaya untuk mewujudkan ketahanan pangan, peningkatan produksi daging sapi harus terus dilakukan dengan melihat sumber daya yang tersedia.

Menurut Djuddawi (2013), Indonesia merupakan negara berkembang yang berbasis pertanian termasuk 
di dalamnya peternakan. Pemenuhan kebutuhan daging di Indonesia belum bisa terpenuhi oleh produk domestik sehingga nilai impor daging sapi ataupun bakalan sapi masih tinggi. Ditjen PKH (2018) memaparkan bahwa prognosa produksi daging sapi di dalam negeri tahun 2018 sebesar 403.668 ton dan perkiraan kebutuhan daging sapi di dalam negeri tahun 2018 sebesar 663.290 ton. Diakses dari kompas.com, bahwa kebutuhan nasional Indonesia per tahun 2020 membutuhkan sekitar 700.ooo ton daging sapi, namun produksi dalam negeri hanya mampu menutupi sampai 400.0000 ton. Angka tersebut meperlihatkan bahwa produksi daging sapi Indonesia masih rendah.

Kabupaten Grobogan adalah kabupaten yang memiliki 19 kecamatan. Grobogan dalam angka 2018 menunjukan bahwa Kecamatan Pulokulon pada tahun 2014 memiliki populasi sapi potong sebesar 18.858 ekor, Populasi ternak sapi potong pada tahun 2017 berjumlah 16.743 ekor sedangkan tahun sebelumnya berjumlah 16.763 ekor. Kecamatan Pulokulon adalah kecamatan dengan populasi sapi potong terbanyak setelah Kecamatan Gabus.

Tabel 1. Populasi Ternak Sapi Potong di Kabupaten Grobogan

\begin{tabular}{|c|c|c|c|}
\hline Kecamatan & Ternak (ekor) & Kecamatan & Ternak (ekor) \\
\hline Kedungjati & 1.893 & Tawangharjo & 5.813 \\
\hline Karangrayung & $4 \cdot 311$ & Grobogan & 6.338 \\
\hline Penawangan & 2.241 & Purwodadi & 9.082 \\
\hline Toroh & 16.166 & Brati & 2.943 \\
\hline Geyer & 16.801 & Klambu & 542 \\
\hline Pulokulon & 18.858 & Godong & 459 \\
\hline Kradenan & 15.180 & Gubug & 113 \\
\hline Gabus & 19.464 & Tegowanu & 176 \\
\hline Ngaringan & 14.725 & Tanggungharjo & 666 \\
\hline Wirosari & 15.553 & & \\
\hline
\end{tabular}

Sumber: Kabupaten Grobogan dalam angka, 2018.

Hasil evaluasi penggunanaan tanah (EPT) tahun 1983 Kecamatan Pulokulon memiliki luas 13.365 hektar. Pada tahun 2018, ketersediaan pakan dari limbah tanaman pangan mencapai 6.186 hektar dari luas panen. Melihat potensi yang ada, didukung dengan permintaan komoditas sapi potong baik dari dalam maupun dari luar daerah, serta masih adanya import daging sapi potong secara nasional maka Kecamatan Pulokulon Kabupaten Grobogan berpotensi menjadi pemasok sapi potong.

Berdasarkan uraian tersebut, diperlukan adanya suatu penelitian yang mengkaji tentang analisis potensi hijauan pakan untuk pengembangan usaha ternak sapi potong. Oleh sebab itu, peneliti tertarik melakukan penelitian tentang analisis daya dukung hijauan pakan ternak di Kecamatan Pulokulon Kabupaten Grobogan untuk pengembangan usaha ternak sapi potong.

\section{METODOLOGI PENELITIAN}

Penelitian dilaksanakan mulai bulan Februari sampai bulan April tahun 2020. Pemilihan lokasi dilakukan secara purposive sampling dengan pertimbangan peneliti bahwa yang dijadikan lokasi penelitian adalah salah satu kecamatan yang memiliki populasi sapi potong yang masuk dalam urutan 5 (lima) besar populasi sapi potong dari 19 (sembilan belas) kecamatan di Kabupaten Grobogan dan memiliki luas lahan sawah terluas di Kabupaten Grobogan sehingga memiliki potensi hijauan lebih banyak dari wilayah lain.

Sumber data yang digunakan adalah data sekunder yang diperoleh dari instansi terkait diantaranya Badan Pusat Statistik (BPS) dan Dinas Peternakan dan Dinas Pertanian. Metode dasar yang digunakan dalam penelitian ini adalah deskriptif analisis. Analisis deskriptif digunakan untuk menggambarkan kondisi yang tengah terjadi pada saat penelitian dilaksanakan di wilayah Kecamatan Pulokulon.

Alat analisis yang digunakan yaitu IDD (indeks daya dukung) pakan. Analisis indeks daya dukung (IDD) pakan ternak dilakuakan untuk mengetahui ketersediaan pakan yang ada di wilayah Kecamatan Pulokulon. IDD (indeks daya dukung) pakan dihitung berdasarkan satuan bahan kering (BK) per tahun terhadap kebutuhan satu satuan ternak (1 ST) per tahun. Sumanto dan Juarini (2006) menjelaskan bahwa kebutuhan pakan minimum ternak ruminansia setiap satu satuan ternak dihitung berdasarkan:

$\mathrm{K}=2,5 \% \times 50 \% \times 365 \times 250 \mathrm{~kg}=1,14$ ton $\mathrm{BK} / \mathrm{th} / \mathrm{ST}$

Keterangan:

K: kebutuhan pakan minimum untuk satuan ternak dalam ton bahan kering tercerna selama satu tahun; 2,5\%: kebutuhan minimum jumlah ransum; 50\%: hijauan pakan (BK) terhadap berat badan; 25okg: asumsi berat hidup satu satuan ternak

Untuk mengetahui tingkat keamanan pakan ternak pada suatu wilayah, dapat dihitung dengan persamaan sebagai berikut:

$$
\text { IDD }=\frac{\text { TPBK }}{\text { JPTR } \times \text { KBK sapi dewasa }}
$$

Keterangan:

TPBK: total produksi bahan kering(kg); JPTR: jumlah populasi ternak ruminansia(ST); KBK: kebutuhan bahan kering(kg/ST)

Kriteria keamanan pakan menurut Ashari (1996) dalam Triyanto et al. (2018) yakni, IDD $\leq 1$ (sangat kritis), IDD > 1-1,5 (kritis), IDD > 1,5-2 (rawan), dan IDD > 2 (aman). Kemudian untuk mengetahui kapasitas penambahan ternak maka hasil kemampuan wilayah (ST) dikurangi populasi ternak (ST). Kapasitas kemampuan wilayah di hitung menggunakan rumus sebagi berikut: 


\section{HASIL DAN PEMBAHASAN}

Kecamatan Pulokulon merupakan kecamatan yang berada di Kabupaten Grobogan Provinsi Jawa Tengah. Jarak dari Utara ke Selatan $\pm 13 \mathrm{~km}$ dan jarak dari Barat ke Timur $\pm 9 \mathrm{~km}$ dengan ketinggian \pm 45 meter di atas permukaan laut (MDPL). Berdasarkan hasil evaluasi penggunaan tanah (EPT) 1983. Kecamatan Pulokulon mempunyai luas 13.365 ha yang terdiri dari 5.675,49 ha lahan sawah dan 7.689,32 ha lahan tanah kering. Kecamatan Pulokulon dari sebelah Barat berbatasan langsung dengan Kecamatan Toroh dan Kecamatan Purwodadi, di sebelah Utara berbatasan dengan Kecamatan Tawangharjo, di sebelah Timur berbatasan dengan Kecamatan Kradenan dan di sebelah Selatan berbatasan dengan Kecamatan Tangen Kabupaten Sragen. Kecamatan Pulokulon memiliki 13 desa dengan jumlah penduduk 108.422 jiwa atau 36.003 KK. Secara keseluruhan kepadatan penduduk Kecamatan Pulokulon adalah 811,25 jiwa $/ \mathrm{km}^{2}$.

Tabel 2. Populasi Ternak Ruminansia (ST)

\begin{tabular}{|c|c|c|c|}
\hline Jenis ternak & Populasi (ekor) & Faktor konversi & Jumlah (ST) \\
\hline Sapi potong & 16.741 & 0,7 & $11.718,70$ \\
\hline Kuda & 26 & 0,7 & 18,20 \\
\hline Kambing/domba & 9.073 & 0,06 & 544,38 \\
\hline Total & 25.840 & & $12.281,28$ \\
\hline
\end{tabular}

Keterangan: Menurut Juarini dan Sumanto (1999) nilai faktor konversi adalah o,8 untuk kerbau, 0,7 untuk sapi, o,06 untuk kambing/domba dan untuk kuda disetarakan dengan sapi

Tabel 2. menunjukkan, Kecamatan Pulokulon memiliki populasi ternak 12.281,28 ST dengan kebutuhan pakan 14.000,66. Desa Randurejo adalah wilayah dengan kebutuhan pakan paling banyak yaitu 1579,83 ton BK/th dengan populasi ternak 1385,82 ST. Wilayah lain yang membutuhkan pakan di atas 1000 ton BK adalah Desa Mluwokarangtalun, Pojok, Jatiharjo, Sidorejo, Tuko, Panunggalan, dan Desa Pulokulon dengan populasi ternak lebih dari 850,00 ST. Sedangkan Desa Jatiharjo, Mangunrejo, Jetaksari, jambon, Karangrejo dan Sembungharjo memiliki kebutuhan pakan untuk ternak kurang dari 1000 ton $\mathrm{BK} / \mathrm{th}$.
Tabel 3. Ketersediaan Pakan Limbah Pertanian di Kecamatan Pulokulon

\begin{tabular}{lrcccc}
\hline $\begin{array}{c}\text { Jenis } \\
\text { limbah }\end{array}$ & $\begin{array}{c}\text { Luas la- } \\
\text { han (ha) }\end{array}$ & $\begin{array}{c}\text { Produksi } \\
\text { BK (ton/ } \\
\text { ha) }\end{array}$ & $\begin{array}{c}\text { Frek. } \\
\text { Panen }\end{array}$ & $\begin{array}{c}\text { Indeks } \\
\text { terman- } \\
\text { faatkan }\end{array}$ & $\begin{array}{c}\text { Jumlah } \\
\text { produksi } \\
\text { (ton BK/th) }\end{array}$ \\
\hline Padi & 9.513 & 2,5 & 2 & 0,3 & $14.269,50$ \\
Jagung & 11.148 & 6 & 1 & 0,3 & $20.066,40$ \\
Kedelai & 12.348 & 2,5 & 1 & 0,3 & $9.261,00$ \\
\hline Total & 33.009 & & & & $43.596,90$ \\
\hline
\end{tabular}

Sumber: data sekunder diolah (2020)

Keterangan: Menurut Hill (1988) dalam Daud (2009) menjelaskan bahwa asumsi produksi bahan kering tanaman jagung 6.0 ton/ha, padi 2,5 ton/ha dan kedelai 2,5 ton/ha. Angka indeks termanfaatkan adalah asumsi menurut Sumanto et al. (2004) dalam Triyanto (2018)

Keterangan: Anggraeni dan Putra (2017) untuk produksi hijauan alami setiap 1(satu) hektar lahan tegalan memiliki produksi 2,875 ton BK/th, lahan pekarangan 0,53 ton $\mathrm{BK} /$ th dengan frekuesi panen 2 kali, hutan negara o,6 tonBK/ha/th, dan lahan lainnya 0,75 ton $\mathrm{BK} / \mathrm{th} / \mathrm{ha}$.

Daya dukung pakan ternak merupakan kemampuan penyediaan hijauan pakan ternak dari suatu wilayah administratif. Hijauan pakan yang dihitung adalah rumput yang tumbuh alami maupun hasil dari limbah pertanian. Menurut Wantesen (2016) tingkat ketersediaan hijauan makanan ternak pada suatu wilayah merupakan salah satu faktor yang sangat penting dalam meningkatkan populasi dalam keberhasilan pengembangan ternak khususnya ternak sapi.

Tabel 5 menunjukkan bahwa ketersediaan pakan di Kecamatan Pulokulon 48.025,14 ton BK/ th, dengan nilai IDD 3,43, artinya ketersediaan pakan di wilayah Kecamatan Pulokulon tergolong aman. Menurut Juarini dan Sumanto (1999) hal ini memberikan makna bahwa wilayah bersangkutan mampu menampung bahkan mempunyai potensi untuk di tingkatkan populasi ternaknya. Menurut Yuniar et al. (2016) semakian tinggi nilai IDD hijauan makan ternak di kecamatan tersebut, maka semakin diprioritaskan untuk dikembangkan. Wilayah dengan nilai IDD tertinggi yaitu Desa Mluwokarangtalun 5,36 Pojok 5,20, Jatiharjo 5,02, Randurejo 4,56, dan

Tabel 4. Ketersediaan Pakan Limbah Pertanian di Kecamatan Pulokulon

\begin{tabular}{|c|c|c|c|c|c|}
\hline Jenis lahan & $\begin{array}{c}\text { Luas } \\
\text { penggunaan (ha) }\end{array}$ & $\begin{array}{l}\text { Produksivitas pakan } \\
\text { (ton } \mathrm{BK} / \mathrm{ha} / \text { th) }\end{array}$ & $\begin{array}{c}\text { Faktor } \\
\text { konservasi }\end{array}$ & $\begin{array}{c}\text { Indeks } \\
\text { termanfaatkan }\end{array}$ & $\begin{array}{c}\text { Jumlah produksi (ton } \\
\text { BK/th) }\end{array}$ \\
\hline Tegal & $1.393,30$ & 2,88 & 1,00 & 0,5 & $2.002,86$ \\
\hline Pekarangan & $2.170,56$ & 0,53 & 2,00 & 0,5 & $1.150,40$ \\
\hline Hutan negara & $3 \cdot 596,60$ & 0,60 & 1,00 & 0,5 & $1.078,98$ \\
\hline Lainnya & 522,68 & 0,75 & 1,00 & 0,5 & 196,01 \\
\hline Total & $7.683,13$ & & & & $4.428,24$ \\
\hline
\end{tabular}

Sumber: data sekunder diolah (2020). 
Tabel 5. Nilai IDD, Kemampuan Wilayah dan Kapasitas Penambahan Ternak di Kecamatan Pulokulon

\begin{tabular}{|c|c|c|c|c|c|c|c|}
\hline No & Desa & $\begin{array}{c}\text { Ketersediaan } \\
\text { pakan (ton BK/ } \\
\text { th) }\end{array}$ & $\begin{array}{c}\text { Jumlah ternak } \\
\text { (ST) }\end{array}$ & $\begin{array}{c}\text { Keb.pakan } \\
\text { (ton BK/th) }\end{array}$ & IDD & $\begin{array}{c}\text { Kapasitas } \\
\text { tampung (ST) }\end{array}$ & $\begin{array}{c}\text { Kapasitas } \\
\text { penambahan } \\
\text { ternak (ST) }\end{array}$ \\
\hline 1 & Randurejo & $7.205,82$ & $1.385,82$ & $1.579,83$ & 4,56 & $3.160,45$ & $1.774,63$ \\
\hline 2 & Mlowokarangtalun & $5 \cdot 489,11$ & 899,02 & $1.024,88$ & 5,36 & $2.407,50$ & $1.508,48$ \\
\hline 3 & Pojok & $5 \cdot 307,05$ & 895,66 & $1.021,05$ & 5,20 & $2.327,65$ & $1.431,99$ \\
\hline 4 & Jatiharjo & $4.182,28$ & 727,02 & 828,80 & 5,02 & $1.834,33$ & $1.107,31$ \\
\hline 5 & Sidorejo & $4.037,65$ & $1.362,38$ & $1.553,11$ & 2,60 & $1.770,90$ & 408,52 \\
\hline 6 & Tuko & $3.058,25$ & $1.219,06$ & $1.389,73$ & 2,20 & $1.341,34$ & 122,28 \\
\hline 7 & Panunggalan & $3.210,60$ & 926,28 & $1.055,96$ & 3,04 & $1.408,16$ & 481,88 \\
\hline 8 & Mangunrejo & $2.981,19$ & 639,92 & 729,51 & 4,09 & $1.307,54$ & 667,62 \\
\hline 9 & Jetaksari & $2.267,40$ & 671,62 & 765,65 & 2,96 & 994,47 & 322,85 \\
\hline 10 & Pulokulon & $2.608,60$ & $1.173,36$ & $1.337,63$ & 1,95 & $1.144,12$ & $-29,24$ \\
\hline 11 & Jambon & $2.843,79$ & 775,02 & 883,52 & 3,22 & $1.247,28$ & 472,26 \\
\hline 12 & Karangharjo & $2.300,07$ & 814,68 & 928,74 & 2,48 & $1.008,80$ & 194,12 \\
\hline 13 & Sembungharjo & $2.533,32$ & 791,44 & 902,24 & 2,81 & $1.111,11$ & 319,67 \\
\hline & Total & $48.025,14$ & $12.281,28$ & $14.000,66$ & 3,43 & $21.063,66$ & $8.782,38$ \\
\hline
\end{tabular}

Sumber: Data sekunder diolah (2020)

Mangunrejo 4,09. Wilayah dengan nilai IDD 3,00 sampai dengan 4,00 yaitu Jambon, Panunggalan. Sementara wilayah dengan nilai IDD kurang dari 3 yaitu Desa Pulokulon, Tuko, Sidorejo, Sembungharjo, Jetaksari dan Karangrejo.

Kecamatan Pulokulon memiliki populasi ternak sejumlah 12.281,28 ST. Kapasitas kemampuan wilayah kecamatan Pulokulon mampu menampung ternak sejumlah 21.063,66 ST. Berdasarkan kapasitas kemampuan wilayah, Kecamatan Pulokulon mampu menambah populasi ternak sejumlah 8.782,38. Secara penyebaran, semua wilayah di Kecamatan Pulokulon mampu menambah populasi ternak, kecuali di desa pulokulon, karena nilai IDD wilayah tersebut menunjukan nilai rawan.

\section{SIMPULAN DAN SARAN}

Kecamatan Pulokulon memiliki nilai IDD (indeks daya dukung) hijauan pakan 3,43, artinya ketersediaan hijauan pakan di wilayah Kecamaan Pulokulon tergolong aman. Kebutuhan pakan saat penelitian yaitu 14.000,66 ton BK/th dari jumlah yang tersedia 48.025,14 tonBK/th. Dari kapasitas daya tampung wilayah sejumlah 21.063,66 ST, Kecamatan Pulokulon dapat menambah populasi ternak sejumlah $8.782,38 \mathrm{ST}$.

Saran yang diberikan adalah optimalisasi pemanfaatan hijauan pakan ternak dari limbah pertanian maupun hijauan alami.

\section{DAFTAR PUSTAKA}

Anggraini, Nova dan Putra, R. A. 2017. Analisis Potensi Wilayah dalam Pengembangan Peternakan Sapi Potong Di Kecamatan Sijunjung Kabupaten Sijunjung. Jurnal Agrifo vol.2 no 2
Arsyad, L. 2015. Ekonomi Pembangunan Ed-5. Yogyakarta: UPP STIM YKPN

[BPS] Badan Pusat Statistik Kabupaten Grobogan. 2018. Kabupaten Grobogan Dalam Angka 2018. Grobogan

[BPS] Badan Pusat Statistik Kabupaten Grobogan. 2018. Kecamatan Pulokulon Dalam Angka 2018. Grobogan

[BPS] Badan Pusat Statistik Kabupaten Grobogan. 2019. Kecamatan Pulokulon Dalam Angka 2019. Grobogan

Djuddawi, Rachmiyati., et al. 2013. Buku Saku Perbibitan Ternak Sapi Potong. Direktorat perbibitan Ternak.Jakarta

[Ditjen PKH] Direktorat Jendral Peternakan dan Kesehatan Hewan. 2018. Arah Pembangunan Peternakan Indonesia Menuju Swasembada Protein Hewani. Diakses 3 Desember 2019 dari http://ditjenpkh.pertanian.go.id/arahpembangunan-peternakan-indonesia-menujuswasemba-protein-hewani

Juarini, E dan Sumanto. 1999. Lahan Potensial Untuk Penyebaran Dan Pengembangan Peternakan Di Provinsi Bali. Seminar nasional peternakan dan veteriner 1999. Balai penelitian ternak. Bogor

Mahardika, W. A. 2020. Tahun ini Indonesia Impor Daging Sapi Lagi.https://money.kompas. $\mathrm{com} / \mathrm{read} / 2020 / 01 / 30 / 191000026 /$ tahun-iniindonesia-impor-daging-sapi-lagi

Sumanto dan E. Juarini. 2006. Potensi Kesesuaian Lahan Untuk Pengembangan Ternak Ruminansia Di Provinsi Nusa Tenggara Timur. Proseding Seminar Nasional Teknologi Peternakan Dan Veteriner, Iptek Sebagai Motor Penggerak Pembanguanan Sistem Dan Usaha Agribisnis Peternakan. Bogor 4-5 Agustus 2004. Pusbanglitan. Bogor 
Triyanto., R., E. Siti, dan Purnomo, S. H. 2018. Analisis Daya Dukung Wilayah Pengembangan Sapi Potong di Kabupaten Gunungkidul. Semnas UNS, vol.2 no.1

Wantesen, E., Dalie, S., dan Oroh, F.N.S. 2016. Daya Dukung Hijauan dan Limbah Tanaman Pangan Pengembangan Populasi Ternak Sapi Potong di Kecamatan Tompaso Kabupaten Minahasa. Pastura vol. 6 No. 1

Yuniar, P. S., Fuah, A. M., dan Widiatmaka. 2016. Daya Dukung Dan Prioritas Wilayah Pengembangan Ternak Sapi Potong di Kota Tangerang Selatan. Jurnal Ilmu Produksi Dan Teknologi Hasil Peternakan. Vol. 04 No.1 Januari 2016 